\title{
Preliminary evaluation of Brazilian green propolis as coadjuvant of a subunit vaccine
}

\section{against lethal leptospirosis}

\author{
Avaliação preliminar da própolis verde brasileira como coadjuvante de uma vacina de subunidade \\ contra a leptospirose letal
}

Evaluación preliminar del propóleo verde brasileño como coadyuvante de una vacuna de subunidad contra la leptospirosis letal

Received: 09/22/2021 | Reviewed: 09/27/2021 | Accept: 09/27/2021| Published: 09/29/2021

\author{
Michel Quevedo Fagundes \\ ORCID: https://orcid.org/0000-0002-9163-4150 \\ Universidade Federal de Pelotas, Brasil \\ E-mail: michelqf@gmail.com \\ Amilton Clair Pinto Seixas Neto \\ ORCID: https://orcid.org/0000-0003-2003-4980 \\ Universidade Federal de Pelotas, Brasil \\ E-mail: amiltonseixas@gmail.com \\ Samuel Rodrigues Felix \\ ORCID: https://orcid.org/0000-0002-2724-692X \\ Instituto Federal de Educação, Ciência e Tecnologia. Brasil \\ E-mail: samuelrf@gmail.com \\ Flávia Aleixo Vasconcellos \\ ORCID: https://orcid.org/0000-0003-4174-3321 \\ Universidade Federal de Pelotas, Brasil \\ E-mail: aleixo.fv@gmail.com \\ Geferson Fischer \\ ORCID: https://orcid.org/0000-0002-3521-395X \\ Universidade Federal de Pelotas, Brasil \\ E-mail: geferson.fischer@gmail.com \\ Marco Alberto Medeiros \\ ORCID: https://orcid.org/0000-0002-1584-7234 \\ Fundação Oswaldo Cruz, BioManguinhos, Brasil \\ E-mail: medeiros@bio.fiocruz.br \\ Éverton Fagonde da Silva \\ ORCID: https://orcid.org/0000-0002-4226-7235 \\ Universidade Federal de Pelotas, Brasil \\ E-mail: fagondee@gmail.com
}

\begin{abstract}
Vaccination would be preferred to leptospirosis control measures. However, current vaccines are heat killed wholecell bacterins that generate serovar specific protection and several side effects. Modern molecular assays have revealed antigens that may replace traditional whole-cell vaccines. Among these, LigB protein is surface-exposed outer membrane protein of virulent leptospires and therefore potential target of a protective immune response. Some unsuccessful attempts at using these antigens as vaccines have been reported. However, we believe that immune modulation through alternative adjuvants and co-adjuvants may overcome previous setbacks. In this light, our study aimed to evaluate the protective immune response in hamsters vaccinated with $40 \mu \mathrm{g}$ of rLigBNI using oil adjuvant (OA), with or without green propolis (GP) as co-adjuvant. Upon a challenge, all groups immunized with rLigBNI, coupled or not with GP, were highly immunogenic and revealed statistically significant $(\mathrm{p}<0.05)$ protection of hamsters from lethal leptospirosis. Additional studies are being carried out to assess the optimum dose, protection against heterologous challenge, and vaccine dynamics.
\end{abstract}

Keywords: Leptospirosis; Recombinant vaccines; Adjuvant; Brazilian green propolis.

\section{Resumo}

A vacinação é uma medida preferencial para o controle da leptospirose. No entanto, as vacinas atuais são bacterinas, com células inteiras mortas pelo calor, que geram proteção sorovar-específica e apresentam efeitos colaterais. Ensaios moleculares revelaram antígenos que podem substituir as vacinas de células inteiras tradicionais. Entre estes, a proteína de membrana externa LigB, a qual está exposta na superfície de leptospiras virulentas, é um alvo potencial 
para uma resposta imune protetora. Algumas tentativas malsucedidas de usar esses antígenos como vacinas já foram relatadas. No entanto, a modulação imunológica por meio de adjuvantes e coadjuvantes alternativos pode superar contratempos anteriores. Diante disso, nosso estudo objetivou avaliar a resposta imune protetora em hamsters vacinados com $40 \mu \mathrm{g}$ de rLigBNI usando adjuvante oleoso (OA), com ou sem própolis verde (GP) como coadjuvante. Após o desafio, todos os grupos vacinados com rLigBNI, administrado-se ou não GP, revelaram imunogenicidade e imunoproteção estatisticamente significativa $(\mathrm{p}<0,05)$. Estudos adicionais serão realizados para avaliar a dose ideal, a proteção contra o desafio heterólogo e a dinâmica da vacina.

Palavras-chave: Leptospirose; Vacinas recombinants; Adjuvante; Própolis verde brasileira.

\section{Resumen}

La vacunación es una medida preferida para controlar la leptospirosis. Sin embargo, las vacunas actuales son bacterinas, con células enteras muertas por el calor, que generan protección específica de serovariedad y tienen efectos secundarios. Los ensayos moleculares han revelado antígenos que podrían reemplazar a las vacunas tradicionales de células enteras. Entre estos, la proteína de la membrana externa LigB, que está expuesta en la superficie de las leptospiras virulentas, es un objetivo potencial para una respuesta inmune protectora. Se han informado algunos intentos fallidos de utilizar estos antígenos como vacunas. Sin embargo, la modulación inmune a través de adyuvantes y adyuvantes alternativos puede superar los retrocesos previos. Por tanto, nuestro estudio tuvo como objetivo evaluar la respuesta inmunitaria protectora en hámsteres vacunados con $40 \mu \mathrm{g}$ de rLigBNI utilizando adyuvante oleoso (OA), con o sin propóleo verde (GP) como coadyuvante. Después del desafío, todos los grupos vacunados con rLigBNI, con o sin GP, mostraron inmunogenicidad e inmunoprotección estadísticamente significativas $(\mathrm{p}<0,05)$. Se llevarán a cabo estudios adicionales para evaluar la dosis óptima, la protección contra el desafío heterólogo y la dinámica de la vacuna.

Palabras clave: Leptospirosis; Vacunas recombinantes; Adyuvante; Propóleo verde brasileño.

\section{Introduction}

In the last decades, leptospirosis has been recognized as an emergent global public health issue (Costa et al., 2015). The disease is mostly an occupational hazard in developed countries. However, in underdeveloped or developing countries, lack of sanitation, favorable climate conditions, and the presence of reservoir hosts, especially Rattus norvegicus, makes tropical regions ideal for the development of leptospirosis (Hartskeerl et al., 2014; Haake, 2015).

In humans, the initial infection occurs when leptospires in the environment (soil or water) penetrate abraded skin or mucosal membranes. The bacteria then migrate through tissue barriers until it reaches the bloodstream, quickly establishing a systematic infection and compromising several organs, especially the kidney, liver, and lungs (CDC, 2020). The immune response can also be jeopardous, secreting pro-inflammatory cytokines, leading to inflammation and tissue damage, a reaction known as Jarish-Herxheimer (Dhakal et al., 2021).

Vaccines represent a cost-effective approach to prevent neglected tropical diseases. However, leptospirosis vaccines are mostly used in veterinary medicine due to side effects generated by the traditional bacterins (killed, whole-cell suspensions) (Ko et al., 2009). Attempts to circumvent these setbacks include vector-delivered vaccines, subunit vaccines, and DNA vaccines, using recombinant outer membrane proteins (OMPs) as antigens (Adler, 2015). Proteins that have been extensively studied are the leptospiral immunoglobulin-like proteins (Lig). Ligs have biological characteristics that also make them attractive candidates for vaccine development (Haake et al., 2021).

Efforts are being made to circumvent this apparent lack of protection. Several substances have been proposed for the development of new adjuvants, between the most common options, oil adjuvants are still largely used in vaccines for veterinary use, because they potentiate the immune system through the formation of a deposit at the inoculation site, with slow and long release of the antigen (O’Hagan et al., 2001). In this context, propolis has been shown to have adjuvant properties when added to experimental inactivated vaccines against serositis (CHU, 2006), swine herpesvirus type 1 (SuHV-1), and bovine herpesvirus type 5 (BoHV-5) (Fischer et al., 2007). This natural product is a resinous material produced by bees that displays a variety of biological activities against viruses, bacteria, fungi, pathogenic protozoa, and tumor cells (Salatino et al., 2011, Sforcina et al., 2011). 
Thus, this study aimed to assess the protective immune response with a lethal challenge assay in the hamster model vaccinated with recombinant LigBNI antigen using oil adjuvant (OA), with or without green propolis (GP), which only found in Brazil and produced from a plant commonly known as "Alecrim do Campo" (Baccharis dracunculifolia) (Banskota et al., 2001), as a co-adjuvant.

\section{Methodology}

\subsection{Leptospira culture}

For experimental qualitatives and quantitatives methods (Pereira et al., 2018), L. interrogans serovar Copenhageni strain Fiocruz L1-130 was cultivated in Ellinghausen-McCullough-Johnson-Harris (EMJH) liquid medium (Difco Laboratories) at $30^{\circ} \mathrm{C}$. The procedures for the maintenance of the culture and challenge experiments were conducted as previously described (Silva et al., 2007).

\subsection{Cloning, expression, and purification of recombinant proteins}

The recombinant vectors used in this work had been previously constructed. The vector pET/LigBNI, containing the non-identical portion of $\operatorname{LigB}$ (1873-3773 nt), coding for a 633-amino-acid peptide (67kDa). The recombinant vector pET/LigBNI was used to transform E. coli BL21 Star (DE3) cells (Invitrogen). The 6×His-tagged recombinant rLigBNI proteins was expressed and purified by affinity chromatography and characterized by Western blotting. The antibodies used were anti-6×His-tagged monoclonal antibody, diluted 1:3,000 (Sigma-Aldrich); sera from a human leptospirosis patient, diluted 1:500; a goat IgG-anti-rabbit IgG-peroxidase conjugate (Sigma-Aldrich), diluted 1:6,000; and a rabbit IgG-anti-human Ig-peroxidase conjugate (Abcam), diluted 1:2,000.

\subsection{Brazilian green propolis preparation}

Green propolis samples were acquired from Nectar Farmacêutica Ltda. (São Paulo, Brazil) and stored at $-20{ }^{\circ} \mathrm{C}$. The extract was prepared as previously described (Paulino et al., 2002). Briefly, the propolis sample was frozen and macerated with an absolute ethanol solution and kept under agitation at $37^{\circ} \mathrm{C}$ during seven days. Afterwards, the solvent was evaporated and the dry matter dissolved in PBS at a final concentration of $40 \mathrm{mg} / \mathrm{mL}$. The chemical composition of the extract was determined through HPCL (Merck-Hitachi, Germain). The detection of components was monitored at $280 \mathrm{~nm}$ and the data analyzed with Merck-Hitachi D-7000 (Chromatography Data Station, DAD Manager).

\subsection{Animal vaccination}

Thirty-two female Golden Syrian hamsters (Mesocricetus auratus) were individually identified and distributed into four experimental groups. Each treatment group was composed of eight animals with four-week-old. Hamsters were inoculated in the quadriceps muscle on day 0 and a second vaccination of antigen on day 14. Emulsions were prepared by mixing protein fragment preparations with an equal volume of OA. Hamsters were vaccinated with $250 \mu$ per injection site. Groups were composed as follow: (G1) $40 \mu \mathrm{g}$ of rLigBNI+OA; (G2) $40 \mu \mathrm{g}$ of rLigBNI+OA+5 mg of GP; (G3) negative control group was inoculated with PBS+OA; and (G4) $10^{8}$ killed whole-Fiocruz L1-130+OA as a positive control. All doses were adjusted to 500 $\mu \mathrm{L}$. Pre-immune and post-vaccination serum samples were collected on the day before the first vaccination and on the day before challenge, respectively. 


\subsection{ELISA}

To determine the humoral immune response induced by the treatments, serum from each animal was serially diluted and tested by ELISA. A preliminary checkerboard analysis was performed to determine ideal antigen concentrations and primary and secondary antibody dilutions. Polystyrene Microtiter plates were coated with $100 \mathrm{ng} / \mathrm{well}$ of rLigBNI diluted in carbonate-bicarbonate buffer $(\mathrm{pH} 9.6)$ at $4^{\circ} \mathrm{C}$ overnight. After three washes with phosphate-buffered saline (PBS) with $0.05 \%$ Tween 20 (PBS-T), the serum from each animal, diluted 1:6,400, was added in triplicate and incubated for $1 \mathrm{~h}$ at $37{ }^{\circ} \mathrm{C}$. Following three washes with PBS-T, plates were incubated for another $1 \mathrm{~h}$ at $37{ }^{\circ} \mathrm{C}$ with a 1:6,000 dilution of goat polyclonal anti-hamster IgG-peroxidase conjugate (Abcam). After five washes with PBS-T, the color reactions were generated with Ophenylenediamine dihydrochloride (Sigma-Aldrich) and hydrogen peroxide (Sigma-Aldrich). These were allowed to develop for $15 \mathrm{~min}$ and stopped by adding $25 \mu \mathrm{L}$ of $4 \mathrm{~N} \mathrm{H}_{2} \mathrm{SO}_{4}$ to the mixture. The optical densities were read at $492 \mathrm{~nm}$.

\subsection{Challenge of vaccinated animals}

For the vaccine protection experiments, groups of eight hamsters, vaccinated according to protocols described previously, were challenged with an intraperitoneal administration of $10^{3}$ leptospires (20x LD50) 14 days after the second vaccination (Silva et al., 2007). Hamsters were monitored daily for clinical signs of leptospirosis and weight loss. A weight loss of $10 \%$ or more was considered lethal (Coutinho et al., 2011) and animals were euthanized for tissue harvesting, likewise, surviving hamsters on day 21 post-challenge were humanely euthanized. Renal tissue was harvested for culture, and renal, pulmonary, and hepatic tissues were harvested for histopathology studies. Sterilizing immunity was determined based on culture isolation of leptospires (from kidney tissue), identification of leptospirosis-associated pathology and histological detection of leptospires in tissues of surviving hamsters. Dark-field microscopy was performed during an 8-week incubation period to identify positive cultures. Tissue sections were stained with hematoxylin and eosin to assess interstitial nephritis and liver diffuse dissociation.

\subsection{Ethics statement}

The animals were manipulated in accordance with the guidelines and protocol (Protocol number 5238, CEEA-UFPel) approved by the Ethics Committee on Animal Experimentation at Federal University of Pelotas, RS, Brazil.

\subsection{Statistical analysis}

Statistical analyses for the ELISAs were carried out with Student's T test. The Fisher exact test and Log-rank test were used to determine significant differences in mortality and survival rates, respectively, among the experimental groups. $P$ values of 0.05 or less were considered indicative of statistical significance. All analyses were carried out with GraphPad Prism 4 software (GraphPad Software).

\section{Results}

HPLC analysis of the green propolis sample used in this experiment showed high levels of the phenolic compounds 3,5-diprenyl-4-hydroxycinnamic acid (Artepillin C), 3,5-diprenyl-4-hydroxycinnamic acid (derivate 8) and 3-prenyl-4hydroxycinnamic acid. In this sample of propolis, the flavonoids correspond to $14.74 \%$ of the dried extract (data not shown).

rLigBNI was purified and found to be stable at $4^{\circ} \mathrm{C}$ after dialysis in sterile PBS. Before the formulation with the adjuvant, the proteins were evaluated for their profile by SDS-PAGE and quantified by the Bradford method, revealing a concentration of $0.5 \mathrm{mg} / \mathrm{mL}$. 
Protein formulations were employed in all immuneprotection experiments and as antigens in the ELISA. Recombinant protein-based ELISA analysis was performed with sera from hamsters on day 0 (pre-immune sera) and 14 days after the second vaccination (immune sera). Absorbance values for immune sera were significantly greater $(\mathrm{p}<0.05)$ than pre-immune sera (Figure 1).

Figure 1. Humoral immune response in hamsters vaccinated and negative control measured by ELISA. Results are expressed as the mean absorbance of all animals in each group. Asterisk means $p<0.05$ in comparison to the pre-immune sera. OD: optical density.

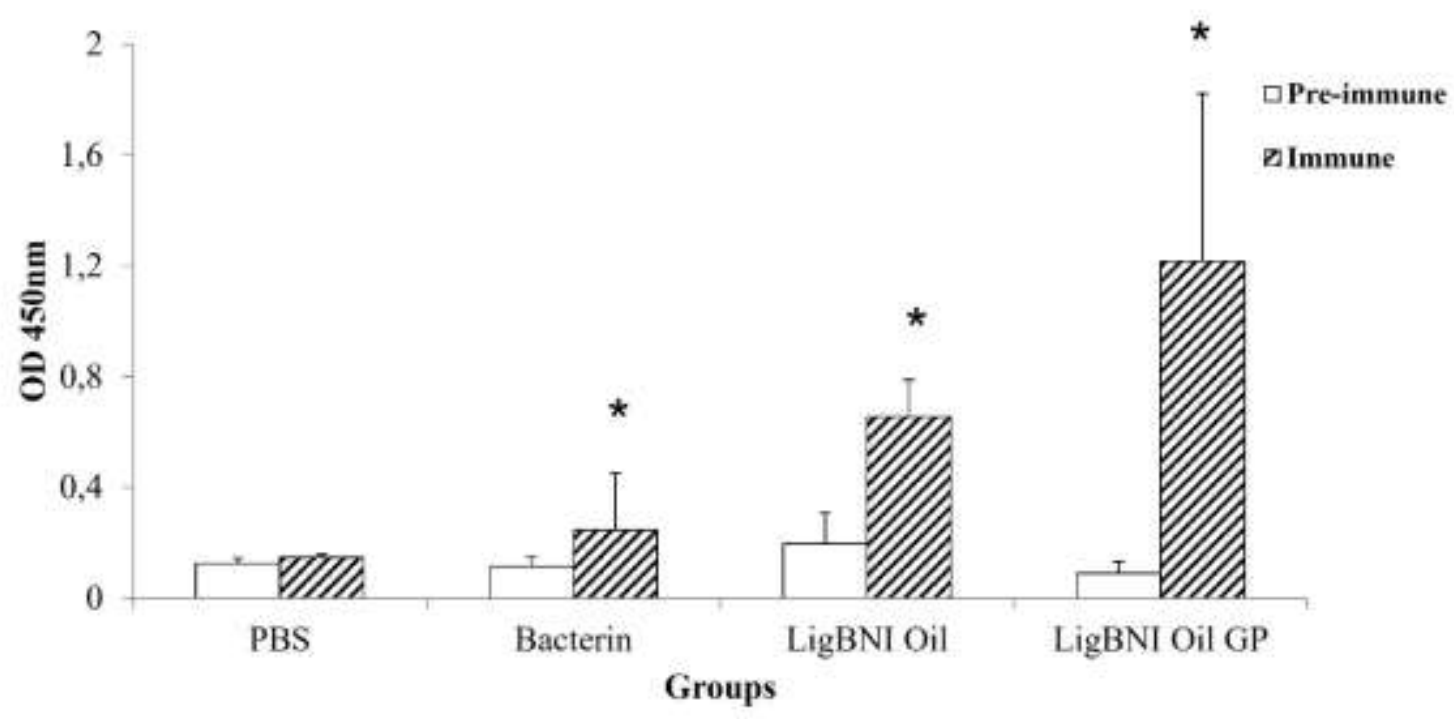

Source: Authors.

Hamsters were challenged with virulent L. interrogans and monitored daily for 21 days or until a $10 \%$ decrease in body weight. The immunization of hamsters with the rLigBNI+OA and rLigBNI+OA+GP afforded $75 \%$ protection against lethal challenge. The positive control afforded $100 \%$ protection and the group receiving PBS showed no protection. Lethality rates are shown in Table 1.

Table 1. Vaccine strategies using rLigBNI against lethal challenge in hamsters.

\begin{tabular}{l|c|c|c}
\hline \multicolumn{1}{c|}{ Group } & Survival/total $(\%)$ & Days until death & $p$ value \\
\hline rLigBNI+OA & $6 / 8(75)$ & 11,12 & $<0.05$ \\
\hline rLigBNI+OA+GP & $6 / 8(75)$ & 12,12 & $<0.05$ \\
\hline PBS+OA (negative control) & $0 / 8(0)$ & $9,9,10,10,10,11$ & - \\
\hline Bacterin+OA (positive control) & $8 / 8(100)$ & - & $<0.05$ \\
\hline
\end{tabular}

Source: Authors.

In the survival analysis through the Log-rank test, the same groups, rLigBNI+OA and rLigBNI+OA+GP, as well as the positive control groups showed statistically significant survival $(\mathrm{p}<0.05)$ when compared with the negative control group. The survival rates are shown in Figure 2. 
Figure 2. The survival of hamsters challenged with virulent L. interrogans. Statistical analyses and graph generation were carried out with GraphPad Prism 4 software systems (GraphPad Software).

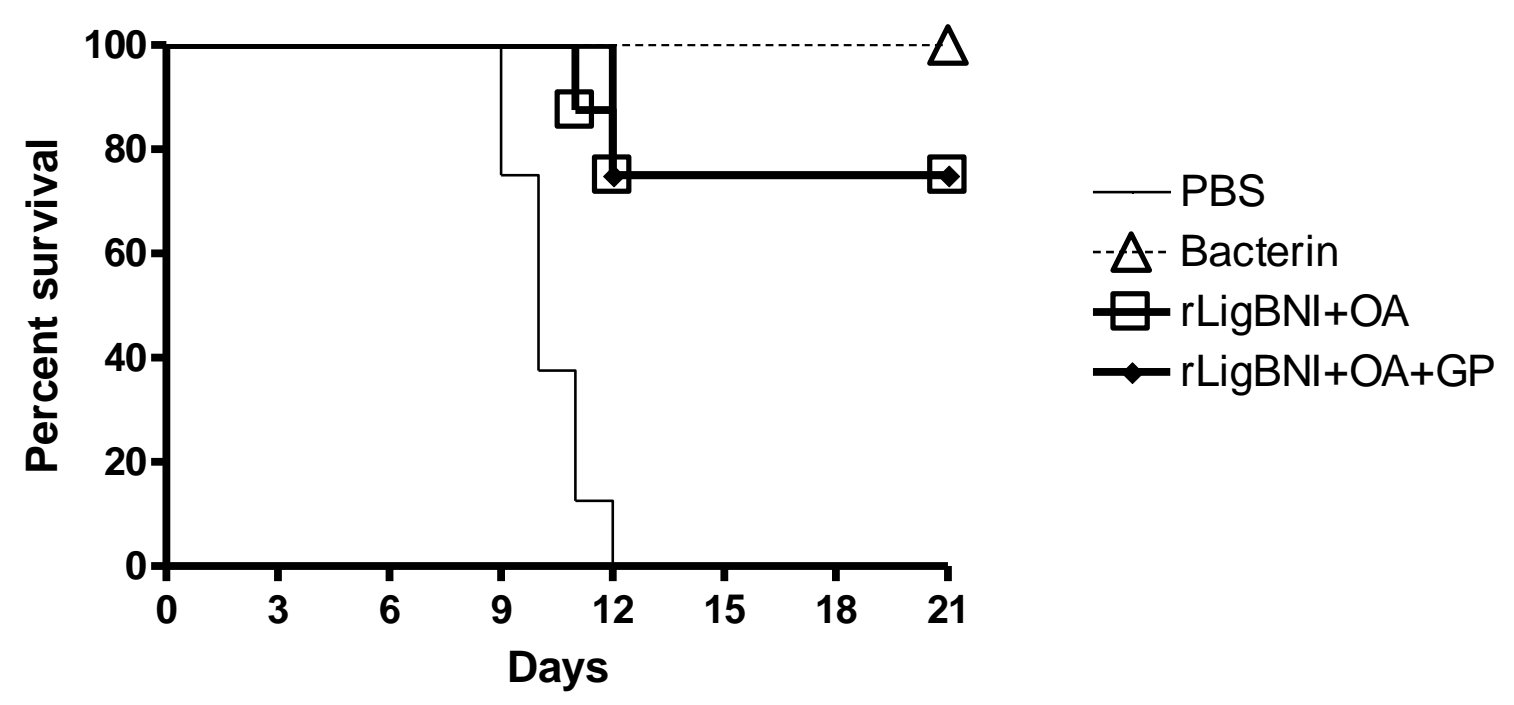

Source: Authors.

Animals that reached the end point during the experiment presented signs of leptospirosis, such as prostration, apathy, dehydration and isolation. Common pathologic alterations were lung hemorrhage, tissue congestion, and jaundice (data not shown).

Bacterial isolation occurred in all immunized groups, showing that none of the preparations afforded sterilizing immunity in $100 \%$ of the animals.

\section{Discussion}

In this study, we assessed the effect of propolis associated with recombinant subunit vaccine on the immune response and protection against lethal leptospirosis challenge. The experimental vaccine formulation rLigBNI+OA and rLigBNI+OA+GP showed the most promising results of protection and significant antibody titers when compared to the negative control. On the other hand, these preparations were not able to prevent kidney colonization or decrease the level of histopathological lesions in animals that survived lethal challenge. It is possible that our use of the non-identical portion of LigB (625-1259aa), including a 63-amino-acid portion that codes for a soluble peptide, may have allowed a correct protein folding, providing proper recognition of important immunogenic epitopes. This result is particularly important if heterologous protection is to be obtained, since LigB is present in all pathogenic leptospires (Cerqueira et al., 2009).

The green propolis sample used in this study showed a predominance of phenolic compounds and cinnamic acid derivatives. These substances are known to stimulate humoral as well as cellular immunity. Although the precise mechanism of action remains unknown, it is possible that the flavonoids stimulated production of cytokines, particularly IL-1 and IL-2, which have mitogenic action for $\mathrm{B}$ and $\mathrm{T}$ lymphocytes. Artepillin $\mathrm{C}$ seems to perform its immunostimulating effect through an increase in the number of auxiliary T lymphocytes (Fischer et al., 2007).

In this work we used hamsters, the recommended animal model for leptospirosis vaccine assessment, challenged with a 1000 leptospires dose of highly pathogenic Leptospira, with a 0\% survival of the controls group. Despite this, our study has limitations. We used a dose of $5 \mathrm{mg}(50 \mathrm{mg} / \mathrm{kg})$ of propolis in the preparations. Previous studies on mice used a dose of 200 
$\mathrm{mg} / \mathrm{kg}$ (Fischer et al., 2007). Future studies should regard pharmacodynamics and optimal propolis concentration for protection.

\section{Final Considerations}

In this study, we describe a leptospirosis vaccine using recombinant LigB antigen with or without GP as a coadjuvant. We showed that rLigBNI+OA, coupled or not with GP, is highly immunogenic and protects hamsters from lethal leptospirosis. Studies are being carried out to assess the optimum dose, protection against other serovars, and vaccine dynamics.

We believe that this approach may result in a future formulation that could replace traditional vaccines against leptospirosis.

\section{Acknowledgments}

We would like to thank the Coordenação de Aperfeiçoamento de Pessoal de Nível Superior - Brasil (CAPES), Conselho Nacional de Desenvolvimento Científico e Tecnológico (CNPq), and Fundação de Amparo à Pesquisa do Estado do Rio Grande do Sul (FAPERGS).

\section{References}

Adler, B. (2015). Leptospira and leptospirosis. Current Topics in Microbiology and Immunology, Berlin, 387, 293.

Banskota, A. H., Tezuka, Y., \& Kadot, S. (2001). Recent progress in pharmacological research of propolis. Phytotherapy Research, 15, 561-571.

CDC. Centers for Disease Control and Prevention. Leptospirosis. Available: https:// https://www.cdc.gov/leptospirosis/exposure/index.html. Acesso em: 16 Set 2021.

Cerqueira, G. M., \& Picardeau, M. (2009). A century of Leptospira strain typing. Infection and Genetic Evolution, 9, 760-768.

Chu, W. H. (2006). Adjuvant effect of propolis on immunization by inactivated Aeromonas hydrophila in carp (Carassius auratus gibelio). Fish and Shelfish Immunology, 21, 113-117.

Costa, F., Hagan, J. E., Calcagno, J., Kane, M., Torgerson, P., Martinez-Silveira, M. S., Stein, C., Abela-Ridder, B., \& Ko, A. I. (2015). Global morbidity and mortality of leptospirosis: A systematic review. PLoS Neglected Tropical Diseases, 9, e0003898.

Coutinho, M. L., Choy, H. A., Kelley, M. M., Matsunaga, J., Babbitt, J. T., Lewis, M. S., Aleixo, J. A. G., \& Haake, D. A. (2011). A LigA three-domain region protects hamsters from lethal infection by Leptospira interrogans. PLoS Neglected Tropical Diseases, 5, e1422.

Dhakal, A. \& Sbar, E. (2021). Jarisch Herxheimer Reaction. In: StatPearls [Internet]. Treasure Island (FL): StatPearls Publishing.

Fischer, G., Cleff, M. B., Dummer, L. A., Paulino, N., Paulino, A. S., Vilela, C. O., Campos, F., Storch, T., Vargas, G., Hübner, S. O., \& Vidor, T. (2007). Adjuvant effect of green propolis on humoral immune response of bovines immunized with bovine herpesvirus type 5. Veterinary immunology and immunopathology, 116, 79-84.

Fischer, G., Conceição, F. R., Leite, F. P. L., Dummer, L. A., Vargas, G., Hübner, S. O., Dellagostin, O. A., Paulino, N., Paulino, A. S., \& Telmo Vidor (2007). Immunomodulation produced by a green propolis extract on humoral and cellular responses of mice immunized with SuHV-1. Vaccine, 25, 12501256.

Hartskeerl, R. A., Collares-Pereira, M., \& Ellis, W. A. (2011). Emergence, control and re-emerging leptospirosis: dynamics of infection in the changing world. Clinical Microbiology and Infection, 17, 494-501.

Haake, D. A., \& Levett, P. N. (2015). Leptospirosis in humans. Current Topics in Microbiology and Immunology, 387, 65-97.

Haake, D. A. \& Matsunaga, J. (2021). Leptospiral Immunoglobulin-Like Domain Proteins: Roles in Virulence and Immunity. Forntiers in immunology, 11, 579907.

Ko, A. I., Goarant, C., \& Picardeau, M. (2009). Leptospira: the dawn of the molecular genetics era for an emerging zoonotic pathogen. Nature Reviews in Microbiology, 7, 736-747.

O’Hagan, D. T., MacKichan, M. L., \& Singh, M. (2001). Recent developments in adjuvants for vaccines against infectious diseases. Biomolecular Enginering, $18,69-85$.

Paulino, N., Scremin, F. M. \& Raichaski, L. B. (2002). Mechanisms involved in the relaxant action of the ethanolic extract of propolis in the guinea-pig trachea in vitro. Journal of Pharmacology, 54, 1-9. 
Research, Society and Development, v. 10, n. 4, e521101220945, 2021

(CC BY 4.0) | ISSN 2525-3409 | DOI: http://dx.doi.org/10.33448/rsd-v10i12.20947

Pereira, A. S., Shitsuka, D. M., Parreira, F. J., \& Shitsuka, R. (2018). Metodologia da pesquisa científica. [e-book]. Santa Maria. Ed. UAB/NTE/UFSM. Disponível em: https://repositorio.ufsm.br/bitstream/handle/1/15824/Lic_Computacao_Metodologia-Pesquisa-Cientifica.pdf?sequence=1. Acesso em: 27 Setembro 2021.

Salatino, A., Fernandes-Silva, C. C., Righi, A. A., \& Salatino, M. L. F. (2011). Propolis research and the chemistry of plant products, Natural Product Reports, $28,925-036$.

Sforcina, J. M., \& Bankova, V. (2011). Propolis: Is there a potential for the development of new drugs?. Journal of Ethonopharmacology, 133, 253-260.

Silva, É. F., Medeiros, M. A., McBride, A. J. A., Matsunaga, J., Esteves, G. S., Ramos, J. G. S., Santos, C. S., Croda, J., Homma, A., Dellagostin, O. A., Haake, D. A., Reis, M. G., \& Ko, A. I. (2007). The terminal portion of leptospiral immunoglobulin-like protein LigA confers protective immunity against lethal infection in the hamster model of leptospirosis. Vaccine, 25, 6277-6286. 